УДК 347.965.3:174

DOI https://doi.org/10.32837/yuv.v0i1.2097

\title{
Я. Фляжнікова,
}

аспірант кафедри організації судових, правоохоронних органів та адвокатури Національного університету «Одеська юридична академія»

\section{ОСОБЛИВОСТІ ДИСЦИПЛІНАРНӦ̈ ВІДПОВІДАЛЬНОСТІ АДВОКАТА ЗА ПОРУШЕННЯ ПРАВИЛ АДВОКАТСЬКОЇ ЕТИКИ}

Адвокатура на всіх етапах розвитку ревно ставилась до підтримання здорового морального клімату у своїй діяльності, дотримання закону i вимог професійної етики членами корпорації у стосунках 3 довірителями, суддями і посадовими особами правоохоронних органів. Це $є$ необхідною умовою отримання суспільного визнання i авторитету корпорації. Відповідно формується й дисциплінарна практика адвокатури. Інколи ці правила вироблялися на основі дисциплінарних проваджень при розгляді проступків адвокатів. Визначення та класифікація дисциплінарних проступків розглядається в широкому розумінні як завдання адвокатської етики, яка $є$ кодексом правил особистої поведінки адвокатів під час здійснення своїх професійних обов'язків та інших правил поведінки.

Окремі питання дисциплінарної відповідальності адвокатів досліджували такі вітчизняні науковці й практики, як: Н.М. Бакаянова [1], Т.Б. Вільчик [2], В.В. Заборовський [3], С.О. Іваницький [4], Д.В. Кухнюк [5] й інші. Однак у наш час проблематика щодо особливостей дисциплінарної відповідальності адвоката за порушення правил адвокатської етики потребує подальшого розгляду та опрацювання.

Метою статті є дослідження особливостей дисциплінарної відповідальності адвоката за порушення правил адвокатської етики, на основі чого визначити їх правове регулювання та сформулювати положення, спрямо- вані на вдосконалення законодавства України.

Чинний закон України (далі - ЗУ) «Про адвокатуру та адвокатську діяльність» у ст. 34 містить перелік дисциплінарних проступків, які є підставою для притягнення адвоката до дисциплінарної відповідальності. Цей перелік хоча і не є вичерпним, проте створює загальну картину тих порушень 3 боку адвоката, які тягнуть за собою дисциплінарну відповідальність.

Достатньо справедливо Н.М. Бакаянова відзначила, що особливістю правового регулювання дисциплінарної відповідальності адвоката в Україні є те, що Закон врегульовує іï лише загалом. Багато питань регламентовано підзаконними актами Ради адвокатів України. 3 урахуванням важливості питання дисциплінарної відповідальності для забезпечення незалежності адвоката, слід визнати таке унормування процедури притягнення адвоката до дисциплінарної відповідальності неприйнятним [1, с. 180].

Відповідно до ч. 2 ст. 34 ЗУ «Про адвокатуру та адвокатську діяльність» дисциплінарним проступком є: порушення вимог щодо несумісності; порушення присяги адвоката України; порушення Правил адвокатської етики (далі - ПАЕ); розголошення адвокатської таємниці або вчинення дій, що призвели до іï розголошення; невиконання або неналежне виконання своїх професійних обов'язків; 
невиконання рішень органів адвокатського самоврядування; порушення інших обов'язків адвоката, передбачених законом [6].

До переліку цих проступків доцільно додати ще пункт 8 - накладення судом стягнення на адвоката за неповагу до суду і порушення порядку у залі судового засідання.

Повага до суду є важливим елементом загальної і правової культури, гарантією своєчасного розгляду та вирішення справ різних категорій у суді. Водночас не слід забувати, що i суд (суддя), зобов'язаний зі свого боку підтримувати авторитет судової влади у суспільстві і власними морально-етичними складовими судового статусу [7, с. 242], а також шляхом притягнення до відповідальності осіб, які виявляють неповагу до суду.

Правова цінність поваги до суду, якщо це справді повага, а не іiі імітація, поєднується 3 конкретною поведінкою адвоката як учасника судочинства, який цю повагу засвідчує, у беззаперечному виконанні процесуальних вимог.

Не менш важливою складовою ПАЕ є дотримання принципу адвокатської таємниці, який до тепер із давніх часів не втратив своєї актуальності, оскільки є необхідною і найбільш важливою умовою довірчих відносин між адвокатом і клієнтом. Так, відповідно до п. 4 ч. 2 ст. 34 Закону, одним iз видів дисциплінарного проступку $€$ розголошення адвокатської таємниці або вчинення дій, що призвели до іï розголошення.

Тому варто наголосити, що адвокатська таємниця може бути розкритою, не тягнучи за собою порушення дисциплінарної справи щодо адвоката, у разі, коли предметом адвокатської таємниці виявилась інформація про злочин, що готується (коли розголошення таємниці - єдина можливість запобігти злочинові). Для забезпечення найважливіших людських цінностей, які й становлять принцип верховенства права, можна допустити певний відступ від вікових традицій щодо абсолютності принципу адвокатської таємниці. Тому пропонується п. 4 ч. 2 ст. 32 ЗУ «Про адвокатуру та адвокатську діяльність» викласти дещо по-іншому, у порівнянні з чинною редакцією, а саме: 4) «розголошення адвокатом відомостей, що становлять адвокатську таємницю, використання ї у своїх інтересах або в інтересах третіх осіб, окрім відомостей про злочин, що готується або вчинено, якщо розголошення адвокатської таємниці - єдина можливість запобігти злочинові».

Водночас слід наголосити, що порушення адвокатської таємниці, яке сталося неумисно, через недбалість адвоката, зокрема, при збереженні документів або через дії його помічника чи стажиста, за якими не здійснювався належний контроль, може бути підставою для пом'якшення відповідальності.

Окрім переліку дисциплінарних проступків, ЗУ «Про адвокатуру та адвокатську діяльність» містить вказівку на те, які діяння не можуть бути підставою для притягнення адвоката до дисциплінарної відповідальності. Відповідно до ч. 3 ст. 34 цього Закону «не $є$ підставою для притягнення адвоката до дисциплінарної відповідальності винесення судом або іншим органом рішення не на користь його клієнта, скасування або зміна судового рішення або рішення іншого органу, винесеного у справі, в якій адвокат здійснював захист, представництво або надавав інші види юридичної допомоги, якщо при цьому не було вчинено дисциплінарного проступку» [6].

Ця норма має виразно декларативний характер і позбавлена реального змісту, оскільки адвоката за будьяких умов не може бути притягнуто до дисциплінарної відповідальності, якщо він не вчинив дисциплінарного проступку. Вона також $€$ зайвою, оскільки відповідно до ч. 1 цієї статті підставою для притягнення адвоката 
до дисциплінарної відповідальності $€$ вчинення ним дисциплінарного проступку. Інших підстав не існує, а тому зазначену норму доцільно виключити із Закону.

Відповідно до ст. 35 ЗУ «Про адвокатуру та адвокатську діяльність» за вчинення дисциплінарного проступку до адвоката може бути застосовано одне 3 таких дисциплінарних стягнень: попередження; зупинення права на заняття адвокатською діяльністю на строк від одного місяця до одного року; для адвокатів України - позбавлення права на заняття адвокатською діяльністю з наступним виключенням з Єдиного реєстру адвокатів України (далі - ЄРАУ), а для адвокатів іноземних держав - виключення з ЕРАУ.

Що ж стосується порушення етичних норм і правил, то варто відзначити наявність не лише приватних, але й публічних аспектів у діяльності адвоката, його відверто негідна поведінка у громадських місцях і в побуті, зокрема, систематичне пияцтво, вживання наркотиків, притягнення до адміністративної відповідальності за порушення громадського порядку не повинні залишатися без уваги з боку адвокатської спільноти, оскільки така поведінка кидає тінь на все адвокатське співтовариство і залежно від конкретної ситуації може розцінюватись як порушення ПАЕ, а відтак і як дисциплінарний проступок.

Чинний Закон недостатньою мірою захищає права особи від несумлінних адвокатів, оскільки ним передбачено можливість повторно отримати статус адвоката тим, хто був його позбавлений. Так, наприклад, дисциплінарна палата кваліфікаційно-дисциплінарної комісії адвокатури (далі - КДКА) Вінницької області прийняла рішення про накладення на адвоката Н. дисциплінарного стягнення у вигляді позбавлення права на заняття адвокатською діяльністю, за те, що він всупереч попередньому рішенню КДКА про зупинення права на заняття адвокатською діяльністю на строк 6 місяців, продовжував адвокатську діяльність. Більше того, адвокат Н. взяв зі свого клієнта відповідну суму гонорару за ведення справи, але при цьому не з'являвся на судові засідання та не відповідав на телефонні дзвінки [8].

Подібні дисциплінарні справи підтверджують необхідність настання найсерйозніших негативних наслідків для адвоката, який вчинив дисциплінарний проступок у вигляді порушення присяги чи ПАЕ. Адвокат, чий статус було припинено, не просто не виконав певних зобов'язань, а не виконав саме конституційного обов'язку шодо надання кваліфікованої правничої допомоги. До таких негативних наслідків, думається, має належати заборона особі повторно отримувати статус адвоката після прийняття рішення про припинення його статусу адвоката. Якщо адвокат дорожить членством у корпораціі, то це $є$ додатковим стимулом для суворого дотримання ним ПАЕ.

Спираючись на вищевикладені аргументи, доцільним є викласти п. 3 ч. 2 ст. 6 Закону у новій редакціï: «3) не може бути адвокатом особа, яка позбавлена права на заняття адвокатською діяльністю безстроково».

Сумнівною також $€$ можливість застосування такого дисциплінарного стягнення, як зупинення права на заняття адвокатською діяльністю на строк від одного місяця до одного року (п. 2 ч. 1 ст. 35 Закону). Подібного стягнення не існує в законодавстві, яке регулює інші види трудової діяльності. До того ж тривала заборона «на професію» може негативно відобразитись на професійному рівні. Тому у майбутньому було б доцільно видалити із Закону цей вид дисциплінарного стягнення.

У ст. 35 необхідно закріпити таке дисциплінарне стягнення, як «догана». Натомість попередження слід розглядати не як стягнення, а виключно як профілактичний захід, 
до якого можна вдатися за результатами розгляду дисциплінарної справи, якщо порушення було незначним і не завдало шкоди.

Тому зазначену статтю варто доповнити такою нормою: «3 урахуванням характеру і серйозності дисциплінарного проступку за результатами розгляду дисциплінарної справи адвокату може бути оголошено попередження».

Не менш важливим є питання процедури порушення дисциплінарного провадження. До осіб, які мають право на звернення до кваліфікаційно-дисциплінарної комісії адвокатури із заявою (скаргою) щодо поведінки адвоката, яка може бути підставою для дисциплінарної відповідальності, відноситься кожен, кому відомі факти такої поведінки. Відповідно до ч. 2 ст. 36 Закону «не допускається зловживання правом на звернення до кваліфікаційної комісії адвокатури, у тому числі ініціювання питання про дисциплінарну відповідальність адвоката без достатніх підстав, і використання зазначеного права як засобу тиску на адвоката у зв'язку із здійсненням ним адвокатської діяльності». Iї̈ застосування на практиці є спірним 3 огляду на труднощі у з'ясуванні мотивів для звернення зі скаргою або заявою. Тому іï у майбутньому вартує виключити.

Сучасне законодавство докладно регулює питання процедури дисциплінарного провадження. Так, відповідно до ст. 37 Закону, воно складається 3 таких стадій: перевірка відомостей про дисциплінарний проступок адвоката; порушення дисциплінарної справи; розгляд дисциплінарної справи; прийняття рішення у дисциплінарній справі. Чинний ЗУ відніс розгляд цих питань до компетенції дисциплінарних палат КДКА.

Закон «Про адвокатуру та адвокатську діяльність» передбачає більш чіткі механізми реагування на дисциплінарні проступки. Для підвищення ефективності таких механізмів у законі визначено чіткий перелік підстав дисциплінарної відповідальності адвоката та прозору і змагальну процедуру розгляду цього питання КДКА. Адвокат при цьому має достатні можливості для висловлення своєї позиції та захисту.

Дисциплінарне провадження в теперішній час припиняється за давністю строку, так як ч. 2 ст. 35 Закону закріплює, що адвокат має бути притягнений до дисциплінарної відповідальності протягом року 3 дня вчинення дисциплінарного проступку.

У майбутньому варто замислитися над тим, щоб зробити виняток із цього правила для випадків порушення ПАЕ. Уявімо собі ситуацію, коли захисник особи, обвинуваченої у вбивстві, виконуючи замовлення слідчих органів умовляє свого клієнта визнати вину й укласти угоду з прокурором, а через декілька років з'ясовується, що злочин було вчинено іншою особою. Право такого адвоката продовжувати надалі свою «правозахисну» діяльність викликає сумнів. Доцільно доповнити ч. 2 ст. 35 Закону такою нормою: «Цей строк не поширюється на випадки порушення присяги адвоката та на проступки, що порочать честь і гідність адвоката або підривають престиж адвокатури».

Основним завданням ВКДКА $€$ розгляд скарг на рішення, діï чи бездіяльність КДКА та узагальнення дисциплінарної практики. Саме в результаті перегляду рішень у дисциплінарних справах комісія зможе приймати корпоративні нормативні акти, які забезпечуватимуть однакове розуміння та застосування етичних ПАЕ, що сприятиме удосконаленню правозастосування у сфері дисциплінарного провадження.

Не менш важливим обов'язком адвоката є дотримання присяги адвоката України, оскільки присяга адвоката уміщує в собі порушення ПАЕ, а ще й до того, що досить суттєво, принцип верховенства, законності, незалежності й конфіденційності 
та сумлінного виконання своїх професійних обов'язків. Це стосується i вимог щодо конфіденційності, де перш за все повинні бути враховані інтереси клієнта.

Однією із небагатьох високорозвинених професійних юридичних спільнот нашої країни є АПУ, яка має за мету впровадити принцип верховенства права в Україні та підвищити рівень правової свідомості у суспільстві.

Асоціація виокремила п'ять вагомих, парадигмально необхідних переваг щодо реформування адвокатури це, зокрема: посилення професійних прав адвокатів та гарантій адвокатської діяльності, удосконалення критеріїв та процедури доступу до професії адвоката, удосконалення інституту дисциплінарної відповідальності адвоката, вдосконалення адвокатського самоврядування, забезпечення прозорих бюджетних та фінансових процедур в органах адвокатського самоврядування [9].

Iз цього вбачається, що українська правова спільнота проявила свідомість та небайдужість до проблем дисциплінарної відповідальності адвоката. У своїй повсякденній діяльності асоціація втілює принципові новації, необхідні для радикального оновлення інституту дисциплінарної відповідальності й усієї адвокатури зокрема. Адже ії мета - вдосконалити правовий механізм та порядок застосування дисциплінарної відповідальності в Україні. Протягом останніх років унаслідок дії законодавства про адвокатуру прослідковується послаблення моральних критеріїв у адвокатській професії. Тому й очевидно, що стан сучасної адвокатури потребує невідкладного законодавчого оновлення.

Відтак дисциплінарну відповідальність адвоката ми можемо розглядати як умисне порушення адвокатом, внаслідок дії чи бездіяльності, своїх професійних обов'язків, які закріплені в ЗУ «Про адвокатуру та адвокатську діяльність», рішеннями, актами з”ізду Ради адвокатів України, Національної асоціації адвокатів України та ПАЕ.

Отже, адвокатура України, як публічна професійна спільнота, повинна бути відкритою для оцінки ii діяльності державними органами та суспільством, відповідальність має бути справедлива, а іiі наслідки співрозмірні. До того ж держава зобов'язана убезпечити адвоката від надмірних переслідувань та безпідставних притягувань його до дисциплінарної відповідальності.

На основі вищевикладеного варто підсумувати: сьогодні виникає необхідність переосмислення кожним адвокатом звичайних прийомів, способів та методів роботи, а також слід сформувати необхідні нові навички професійної діяльності. У наш час критично важливо створити налагоджений механізм дисциплінарної відповідальності адвоката за порушення ПАЕ у найбільш захищений для адвоката спосіб. До того ж досить часто на практиці прослідковуються переважно латентні, а періодично й відкриті випадки правового нігілізму, тому радикально необхідно врятувати професійну культуру і справжню адвокатську етику.

Тому, досліджуючи питання дисциплінарної відповідальності адвокатської практики, очевидно, що деякі питання, які обговорюється сучасною адвокатською спільнотою, потребують вдосконалення. Але хочеться вірити, що адвокатура України протягом найближчого часу створить новий якісно досконалий та справедливий інститут дисциплінарної відповідальності, зокрема і за порушення ПАЕ.

у статті досліджено особливості дисциплінарної відповідальності адвоката за порушення правил адвокатської етики, що є необхідною умовою отримання суспільного визнання й авторитету корпорації. Зазначається, що иі правила вироблялися на основі дисциплінарних 
проваджень під час розгляду проступків адвокатів. Визначення та класифікація дисциилінарних проступків розглядається в широкому розумінні як завдання адвокатської етики, яка є кодексом правил особистої поведінки адвокатів під час здійснення своїх професійних обов'язків та інших правил поведінки.

Важливо зазначити, що чинний закон України «Про адвокаmуру та адвокатську діяльність» у статmі 34 містить перелік дисичиплінарних проступків, які є підставою для притягнення адвоката до дисииплінарної відповідальності. Цей перелік хоча $і$ не є вичерпним, проте створюе загальну картину тих порушень з боку адвоката, які тягнуть за собою дисизиплінарну відповідальність.

Досліджено окремі ситуациї та принципи притягнення адвоката до дисииплінарної відповідальності за порушення правил адвокатської етики. Причому визначено, що чинний закон України "Про адвокаmуру та адвокатську діяльність» недостатньою мірою захищае права особи від несумлінних адвокатів, оскільки ним передбачено можливість повторно отримати статус адвоката тим, хто був його позбавлений.

Необхідно вказати, щзо українська правова спільнота проявила свідомість та небайдужість до проблем дисииплінарної відповідальності адвоката. у своїи повсякденній діяльності асоціація правників України втілюе принциипові новаціі, необхідні для радикального оновлення інституту дисииплінарної відповідальності й усієї адвокатури зокрема. Адже ї̈ мета - вдосконалити правовий механізм та порядок застосування дисциплінарної відповідальності в Україні. Автором визначено, що стан сучасної адвокатури потребує невідкладного законодавчого оновлення.
Пропонується створити налагоднений механізм дисциилінарної відповідальності адвоката за порушення Правил адвокатської етики у найбільш захищений для адвоката спосіб. Оскільки на практиці прослідковуються переважно латентні, а періодично й відкриті випадки правового нігілізму, тому радикально необхідно врятувати професійну культуру $i$ справжню адвокатську етику.

Ключові слова: адвокат, етика, відповідальність, дисциплінарна відповідальність адвоката, правила адвокатської етики.

Fliazhnikova Ya. Specific features of disciplinary liability of lawyer for violation of the rules of lawyer ethics

The article examines the features of the disciplinary liability of a lawyer for violating the rules of lawyer ethics, which is a necessary condition for obtaining public recognition and authority of the corporation. It is noted that these rules were made on the basis of disciplinary proceedings when considering misdemeanors of lawyers. Thear definition and classification of disciplinary offenses considered in a broad sense as a task of legal ethics, which is a code of personal conduct for lawyers in the performance of their professional duties and other rules of conduct.

It is important to note that the current law of Ukraine on the Bar and Advocate Activity in Article 34 contains a list of disciplinary offenses that are grounds for bringing a lawyer to disciplinary responsibility. Although this list is not exhaustive, it creates a general picture of those violations by a lawyer that entail disciplinary action.

Some situations and principles of bringing a lawyer to disciplinary responsibility for violating the rules of lawyer ethics have been studied. Moreover, it is determined that the 
current law of Ukraine on the Bar and Advocate Activity does not sufficiently protect the rights of individuals from dishonest lawyers, as it provides an opportunity to regain the status of a lawyer to those who were deprived of it. It should be noted that the Ukrainian legal community has shown awareness and indifference to the problems of disciplinary liability of a lawyer. In its daily activities, the Ukrainian Bar Association embodies the fundamental innovations necessary for the radical renewal of the institution of disciplinary responsibility and the entire bar in particular. After all, its purpose is to improve the legal mechanism and the procedure for applying disciplinary liability in Ukraine. The author determined that the state of the modern bar needs urgent legislative renewal.

It is proposed to create an established mechanism of disciplinary liability of a lawyer for violation of the Rules of Ethics of Lawyers in the most protected way for a lawyer. Since, in practice, there are mostly latent and periodically open cases of legal nihilism, it is radically necessary to save the professional culture and true legal ethics.

Key words: attorney, ethics, responsibility, disciplinary responsibility of a lawyer, rules of lawyer ethics.

\section{Література}

1. Бакаянова H.M. Імплементація міжнародних принципів дисциилінарної процедури щодо адвокатів у законодавство України. Прикарпатський юридичний вісник. 2017. №1. С. 179-183.

2. Вільчик Т.Б. Дисциплінарна відповідальність адвокатів в країнах ЄC та в Україні. Форум права. 2015. № 4. С. 38-44.

3. Заборовський В.В. Дисииплінарна відповідальність адвоката: поняття та види. Порівняльно-аналітичне право. 2014. № 4. C. 105 .

4. Іванищький С.О. Вибори в адвокатурі: історія, сьогодення, иляхи удосконалення. Адвокат. 2014. № 7. С. 20-26.

5. Кухнюк Д.В. Дисцииллінарна відповідальність адвоката в Україні: проблеми правового регулювання. Цивілістична процесуальна думка. 2016. № 2. С. 75 -79.

6. Закон України «Про адвокаmуру та адвокатську діяльність» від 2013 року. Відомості Верховної Ради. 2013. № 27. Cm. 282.

7. Бринцев В.Д. Стандарти правової держави: втілення у національну модель організаційного забезпечення судової влади: монографія. Харків : Право, 2010. $464 \mathrm{c}$.

8. Матеріали практики КДКА Віннищької області. URL: http: / / osav.vn.ua/ index.php/pravovi-osnovy/rishennia-natsionalnoi-asotsiatsii-advokativ-ukrainy-rady-advokativ-ukrainy-vyshchoi-kvalifikatsiino-dystsyplinarnoi-komisii-advokatury.

9. Відкрите звернення АПУ щзоо реформування адвокатури від 9 листоnaдa 2017 p. URL: http://uba.ua/ukr/ news / $5298 /$. 